"Assessment of the Ukrainian economy in 2000-2015 based on the macroeconomic stabilization pentagon (MSP) model"

\begin{tabular}{|c|c|}
\hline AUTHORS & $\begin{array}{l}\text { Oleksii Lyulyov (D https://orcid.org/0000-0002-4865-7306 } \\
\text { R http://www.researcherid.com/rid/O-7046-2018 }\end{array}$ \\
\hline ARTICLE INFO & $\begin{array}{l}\text { Oleksii Lyulyov (2017). Assessment of the Ukrainian economy in 2000-2015 } \\
\text { based on the macroeconomic stabilization pentagon (MSP) model. Geopolitics } \\
\text { under Globalization, 1(2), 45-52. doi:10.21511/gg.01(2).2017.05 }\end{array}$ \\
\hline DOI & http://dx.doi.org/10.21511/gg.01(2).2017.05 \\
\hline RELEASED ON & Thursday, 28 December 2017 \\
\hline RECEIVED ON & Thursday, 19 October 2017 \\
\hline ACCEPTED ON & Thursday, 21 December 2017 \\
\hline LICENSE & $\begin{array}{l}(c) \text { EY-NG } \\
\text { This work is licensed under a Creative Commons Attribution-NonCommercial } 4.0 \\
\text { International License }\end{array}$ \\
\hline JOURNAL & "Geopolitics under Globalization" \\
\hline ISSN PRINT & $2543-5493$ \\
\hline ISSN ONLINE & $2543-9820$ \\
\hline PUBLISHER & LLC “Consulting Publishing Company "Business Perspectives" \\
\hline FOUNDER & Sp. z o.o. Kozmenko Science Publishing \\
\hline
\end{tabular}

NUMBER OF REFERENCES

13
NUMBER OF FIGURES

5

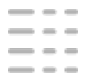

NUMBER OF TABLES

2

(C) The author(s) 2023. This publication is an open access article. 


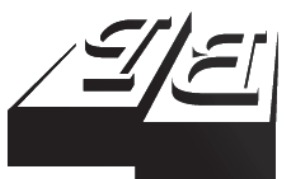

BUSINESS PERSPECTIVES

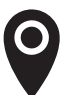

LLC "CPC "Business Perspectives" Hryhorii Skovoroda lane, 10, Sumy, 40022, Ukraine

www.businessperspectives.org

Received on: $19^{\text {th }}$ of October, 2017 Accepted on: $21^{\text {st }}$ of December, 2017

(C) Lyulyov Oleksii, 2017

Lyulyov Oleksii, Ph.D., Associate Professor of the Department of Economics and BusinessAdministration, Sumy State University, Ukraine.

\section{ASSESSMENT OF THE UKRAINIAN ECONOMY IN 2000-2015 BASED ON THE MACROECONOMIC STABILIZATION PENTAGON (MSP) MODEL}

\begin{abstract}
The main task of the article is to assess the development process of the macroeconomic stabilization in Ukraine during 1997-2016. The work shows the results of author's own research, carried out using the method of tools given by director of Finance Institute in Warsaw, Professor of Economics Kolodko. This method is based on the assessment of five key macroeconomic indices: GDP rate growth, unemployment rate, inflation rate, state budget balance to GDP, balance of current turnovers to GDP. The results of calculations show that macroeconomic stability level, which is higher than 0.5 was demonstrated by the country only during 1999-2007, and during this period general internal and external stability is kept. Based on the macroeconomic predictions of GDP rate growth, unemployment rate, approved by the Cabinet of Ministers of Ukraine and on the data extrapolation of consumer price index, state budget balance, current account balance, Ukraine’s MSP profile for 2018-2020 was constructed.
\end{abstract}

Keywords

balance, competitiveness, debt, deficit, economic growth, inflation, macroeconomic stability, unemployment

\section{JEL Classification E63, F43, O11}

\section{INTRODUCTION}

The financial crisis in 2007 was caused by increasing of countries' economic development levels disproportions and their competitiveness. As a result of GDP growth in the world richest countries in 2007, which are included to G7 (Canada $-2.06 \%$, France $-2.36 \%$, Japan $-1.65 \%$, Germany $-3.26 \%$, Italy $-1.47 \%$, Great Britain $-2.55 \%$, the USA - 1.8\%) (World Bank, 2017), only four of them (United States, Japan, United Kingdom, Germany), in average by $2 \%$, are included to ten best countries by the competitiveness index, published in the annual Report about global competitiveness by World Economic Forum (WEF, 2017).

Among the EU countries the highest annual rate of GDP growth in 2007 was fixed in the Baltic States (Estonia - 7.75\%, Latvia - 9.95\%, Lithuania -11.08\%), Slovak Republic (10.8\%) and Luxemburg (8.4\%), however after financial and debt crisis impact in 2009 all EU countries demonstrated negative tendency of the economic growth, total GDP was reduced by $4 \%$. It should be noticed that economies of those countries suffered from the deepest recession, which demonstrated the highest rates of the pre-crisis GDP growth, particularly in Estonia $(-14.72 \%)$, Latvia (-14.33\%), Lithuania (-14.81\%) and Finland (-8.27\%) (World Bank, 2017). Such falling lead to the losses of mentioned economic positions in the rating of global competitiveness index in comparison with $2004-2005$ by 0.52 points in Finland (1 place (5.95) in
This is an Open Access article, distributed under the terms of the Creative Commons Attribution-NonCommercial 4.0 International license, which permits re-use, distribution, and reproduction, provided the materials aren't used for commercial purposes and the original work is properly cited. 
2004-2005, 6 place (5.43) in 2009-2010) and Estonia (20 place (5.08) in 2004-2005, 35 place (4.56) in 2009-2010), 0.37 points - Latvia(44 place (4.43) in 2004-2005, 68 place (4.06) in 2009-2010), 0.27 points - Lithuania (36 place (4.57) in 2004-2005, 53 place (4.30) in 2009-2010) (WEF, 2017).

Since 2010 in order to avoid above misbalances, appeared after crisis, the European committee within the EU took measures oriented to reduce its impact and risk in the future. One of such measures was acceptance of European Parliament and Council Regulations (EU) No. 1176/2011 and No. 1174/2011, November 16, 2011, the first of which concerns prevention and correction of macroeconomic misbalances, and the second - correction of excessive macroeconomic tendencies misbalances in the euro-zone countries (Regulation, 2011a; Regulation, 2011b). According to Regulation (EU) No. 1176/2011 the macroeconomic misbalance is defined as "any trend giving rise to macroeconomic developments which are adversely affecting, or have the potential to adversely affect, the proper functioning of the economy of a Member State or of the Economic and Monetary Union, or of the Union as a whole" (Regulation, 2011b). In this context Scoreboard plays significant role. It consists of fourteen macroeconomic indices (Table 1) monitoring of which is oriented to prevent, reveal and check macroeconomic misbalances and deviations from desired level of competitiveness.

Table 1. Macroeconomic Imbalance Procedure Scoreboard

Source: MIP, 2017

\begin{tabular}{|c|c|c|}
\hline & Indicators & Threshold \\
\hline \multirow{5}{*}{$\begin{array}{l}\text { External } \\
\text { imbalances and } \\
\text { competitiveness }\end{array}$} & Current account balance - \% of GDP (3 year average) & $>-4 \% ;<+6 \%$ \\
\hline & Net international investment position (\% of GDP) & $>-35 \%$ \\
\hline & Real effective exchange rate - 42 trading partners (1) (3 year \% change) & $\begin{array}{c}>-5 \% ;<+5 \%(\mathrm{EA}) \\
>-11 \% ;<+11 \%(\text { Non-EA) }\end{array}$ \\
\hline & Export market share - \% of world exports ( 5 year $\%$ change) & $>-6 \%$ \\
\hline & Nominal unit labor cost index $(2010=100)(3$ year \% change $)$ & $\begin{array}{l}<9 \%(E A) \\
<12 \%(\text { Non-EA) }\end{array}$ \\
\hline \multirow{6}{*}{$\begin{array}{l}\text { Internal } \\
\text { imbalances }\end{array}$} & House price index $(2010=100)$, deflated $(1$ year $\%$ change $)$ & $<6 \%$ \\
\hline & Private sector credit flow, consolidated ( $\%$ of GDP) & $<14 \%$ \\
\hline & Private sector debt, consolidated (\% of GDP) & $<133 \%$ \\
\hline & General government gross debt (\% of GDP) & $<60 \%$ \\
\hline & Unemployment rate (3 year average) & $<10 \%$ \\
\hline & Total financial sector liabilities, nonconsolidated (1 year \% change) & $<16.5 \%$ \\
\hline \multirow{3}{*}{$\begin{array}{l}\text { Employment } \\
\text { indicators }\end{array}$} & Activity rate $-\%$ of total population aged $15-64$ ( 3 year change in $p p)$ & $>-0.2 \%$ \\
\hline & $\begin{array}{l}\text { Long-term unemployment rate }-\% \text { of active population aged } 15-74 \text { (3 year } \\
\text { change in pp) }\end{array}$ & $<0.5 \%$ \\
\hline & $\begin{array}{l}\text { Youth unemployment rate - \% of active population aged 15-24 (3 year } \\
\text { change in pp) }\end{array}$ & $<2.0 \%$ \\
\hline
\end{tabular}

However, despite introduction of the proper policy to prevent macroeconomic misbalance in the countries, according to data of World Bank in 2014, 3 from 28 EU countries had negative tendency of the economic growing (Cyprus - 1.53\%, Finland - 0.63\%, Croatia - 0.35\%), and in 2015 - Greece $(-0.22 \%)$. At the same time, global competitiveness index gap between European economies which takes the highest (Netherlands - 5.57) position in rating of The Global Competitiveness Report in 2016 and the worst (Greece - 4) was 1.57 points (WEF, 2017).

\section{LITERATURE REVIEW AND METHODS}

Director of Finance Institute in Warsaw, Professor of Economics Kolodko (1993) suggests a model of the macroeconomic stabilization pentagon (MSP), based on the study of dynamics and interconnection between five key macroeconomic indices: GDP growth rate $(r)$, unemployment rate $(U)$, inflation rate $(C P I)$, state budget balance to GDP 


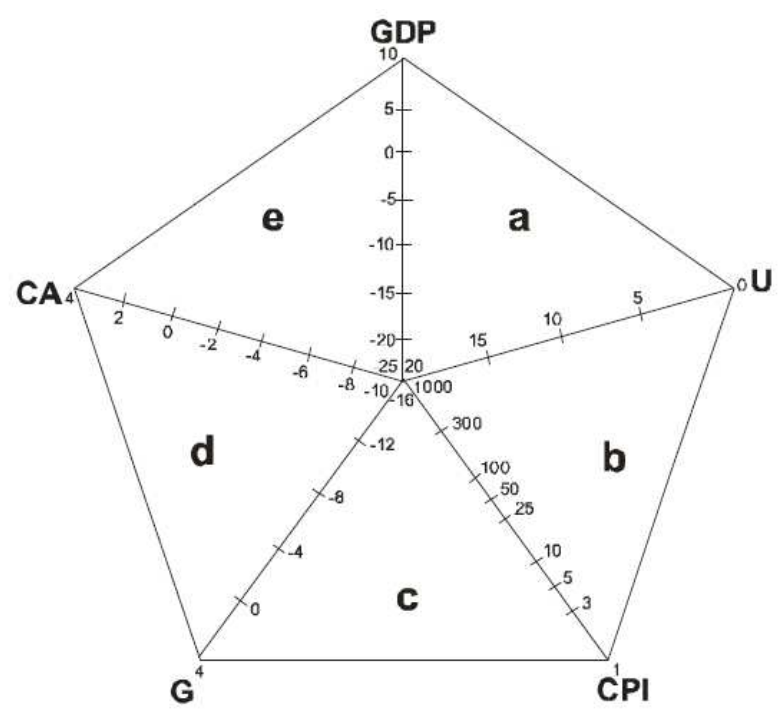

Source: Kolodko, 1993.

Figure 1. The macroeconomic stability pentagon

$(G)$, balance of current turnovers to GDP $(C A)$. This model provides economy review, considering internal and external misbalances. Essence of the MSP model is to assess the situation when the country reaches five aims of the macroeconomic stability:

1) stable economic growth, measured by speed of GDP growth;

2) increase of employment rate, i.e. unemployment rate reduction;

3) increase of the internal balance, considered as inflation rates;

4) balanced state budget, with which internal state debt financing will be supported without inflation effects;

5) balance of the current account has to be supported at the level, which lets to reduce an external debt.

Each of five above indices is a pentagon vertex (Figure 1), based on ratio of which MSP synthetic index is calculated, that is a measure of the surface square, calculated by the formula:

$$
\begin{aligned}
& M S P=[(r \cdot U)+(U \cdot C P I)+(C P I \cdot G)+ \\
& +(G \cdot C A)+(C A \cdot r)] \cdot k,
\end{aligned}
$$

where $\mathrm{k}=1 / 2 \sin 72^{\circ}$.
The optimal situation in economy is when MSP is equal to 1 or $100 \%$, and each of triangle fields, formed as a result of pentagon vertexes correlation is $20 \%$ of its total square. Triangle "a" is limited by the ratio between GDP growth rate and unemployment rate and characterizes the real sphere triangle index. Triangle " $b$ " is a function from unemployment rate and inflation, which forms so called shortageflation or slumpflation triangle. Square of triangle "c" is characterized by the index of inflation and budget (the budget and inflation triangle) is calculated as a ratio between inflation rate and state budget balance. In its turn, triangle " $\mathrm{d}$ " is calculated as a ratio between state budget balance and balance of current turnovers to GDP and creates the financial balance triangle. The last triangle "e" is called ext ternal sector triangle, since it is originated from segments, which show balance of current turnovers to GDP and GDP growth rate.

Realization of macroeconomic stability tasks is to support a relative balance between internal and external factors:

$$
M S P=M S P 1+M S P 2
$$

where $M S P 1=a+b+c$ - indicator, which characterizes impact of internal factors on the macroeconomic stability in the given country;

$M S P 2=d+e-$ indicator, which characterizes external factors' impact. 
Table 2. Descriptive statistics of the MSP model main key indices

Source: based on authors' calculations.

\begin{tabular}{l|c|c|c|c}
\hline Constant & Average value & Standard fluctuations & Minimum value & Maximum value \\
\hline $\mathrm{r}$ & 1.89275 & 6.738748 & -14.8 & 12.1 \\
$\mathrm{U}$ & 8.77 & 1.628076 & 6.4 & 11.6 \\
$\mathrm{CPI}$ & 13.51007 & 10.53562 & -0.6 & 43.3 \\
$\mathrm{G}$ & -1.52011 & 2.984758 & -6.5419 & 6.8 \\
$\mathrm{CA}$ & -0.6803156 & 5.407193 & -9.2 & 10.3 \\
\hline
\end{tabular}

Balance of subindices MSP1 and MSP2 means that country's economy does not depend on the international markets and currency exchange rates, but at the same time is a closed economy with old technologies and lack of investment. It is supposed that level of country's general economic efficiency is directly proportional to the pentagon surface. At the same time, the balanced form of pentagon shows more balanced growing of economy. From the viewpoint of economy growing and stability, $M S P$ is preferable to be supported at highest degree. High rates of MSP may assist strengthening of the government control, particularly, increasing available financial resources, and thus, creation of the concrete system or sectoral policy in this country. On the other hand, low rate of MSP has to play a significant role to achieve an effective realization of public interests, implemented in the managerial processes of state institutions and economic processes support.

Extensive research with MSP model use for potential analysis of growing and stabilization in many countries is considered in works of scientists and economists (Żuchowska, 2013; Calin, 2013;
Malina \& Mierzwa, 2014; Hurduzeu \& Lazar, 2015; Ionita, 2015).

The objective of the research is to assess macroeconomic stability in Ukraine through the model, which is based on the macroeconomic stability pentagon conception, given by Kolodko.

\section{RESULTS}

Peculiarities of Ukraine's main key indices during 1997-2016, on the basis of which MSP is calculated, are shown in the Table 2.

GDP average annual growth in 1997-2016 was $1.89 \%$. During 1999-2007 real GDP growth was observed from 102.5 billion UAH to 587.392 billion UAH, caused mostly by government's anti-inflation policy, in average consumer price index was $12 \%$, in 2002 deflation at the level of $0.6 \%$ was fixed in Ukraine. In its turn, the unemployment average rate between 1999 and 2007 was $8.77 \%$, besides; the least value of this index was fixed in 2005 at the level of $7.2 \%$. Balance of current turnovers dur-

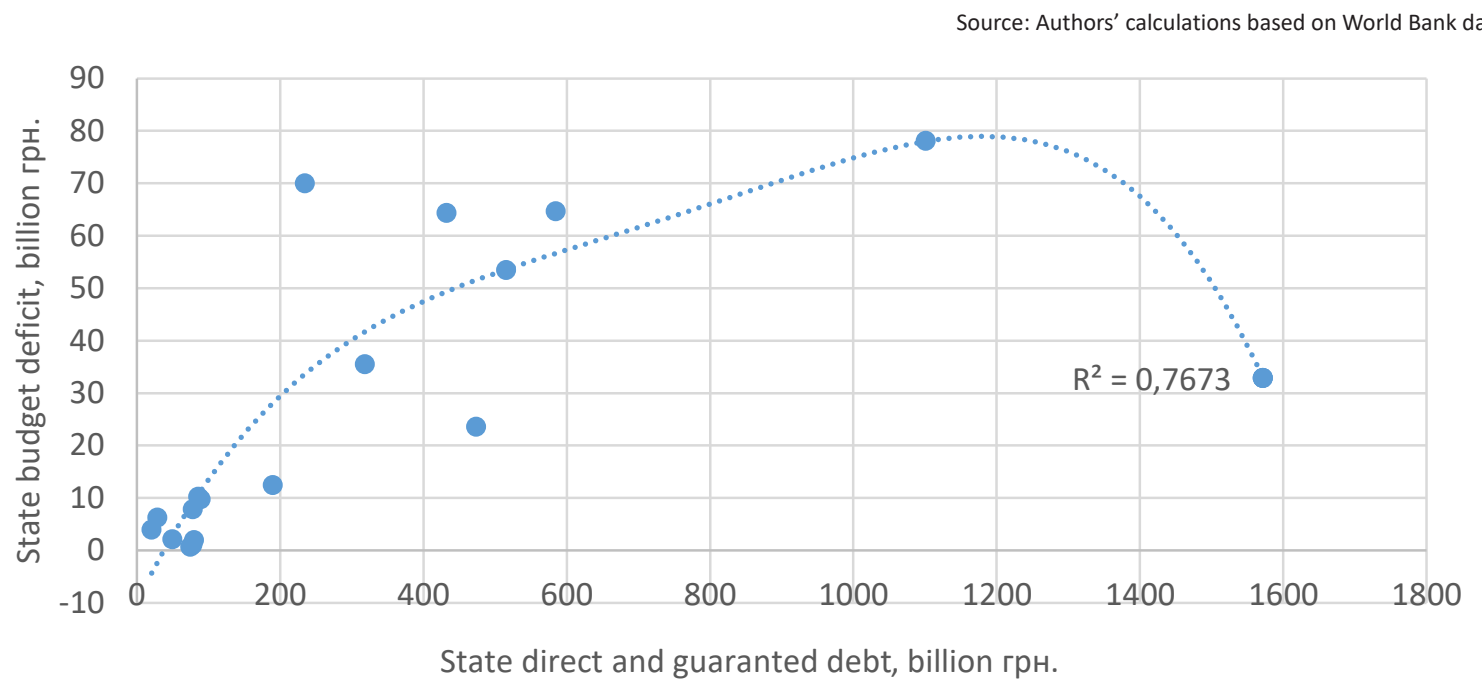

Figure 2. Dependence of the Ukraine's state debt size on state budget deficit during 1997-2016 


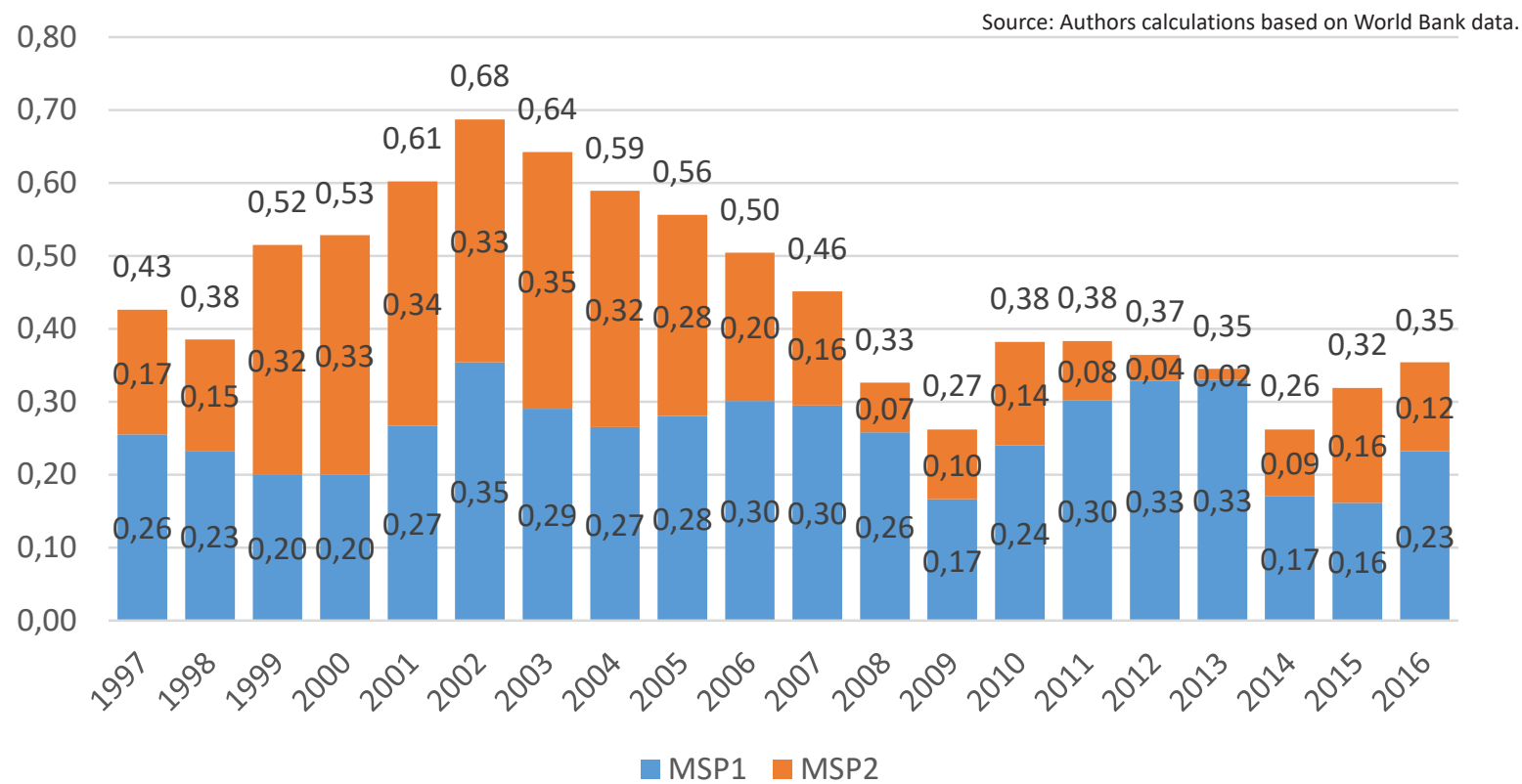

Figure 3. Indicators of internal and external factors impact on the macroeconomic stability in Ukraine in 1997-2016

ing the analyzed period was also fixed at the high level to $10.3 \%$ of GDP in 2004. Despite positive tendencies of nominal and real GDP growth from 1999-2007, since 2000 there was adverse consolidated state budget in Ukraine, justified first by the state debt stability. Determination coefficient of the state debt dependence on state budget deficit is $77 \%$ (Figure 2). During 2000-2007 the ratio of state budget deficit to GDP was gradually reduced to $0.89 \%$, and did not exceed $3 \%$. On the one hand, it proves the non-destabilizing character of this index impact on country's economy, and on the other hand, essential misbalance policy concerning the financial provision of state's development.

The largest falling of main macroeconomic indices was in Ukraine during 2008-2013, influenced by the global financial and economic crisis. At first since 2000, both in absolute and in relative terms GDP was decreased in 2009 in comparison with previous period (34.7 billion UAH or $14.8 \%$ ), and average falling of economy during that period was $0.44 \%$. State budget deficit of Ukraine was increased to 64.7 billion UAH in 2013 (or $4.3 \%$ of GDP) and almost seven times exceeded its amount in 2007.

During the next 2014-2016, in absolute term amount of GDP was being increased demonstrating a positive tendency, however rates of index growing were characterized with tendency to slowdown in 2014 and 2015 and were -6.55 and $-9.87 \%$ accordingly, and only in 2016 fastened growing by $2.3 \%$. Investigating factors of macroeconomic instability in the economic model development system, authors (Skrypnychenko et al., 2012) point out that only annual economic growth over 5\% allows to escape beyond the existing restrictions of economy development in Ukraine. Therefore such growth is based on the following directions: withdrawal of non-economic and exhausted capacities; generating of new technologies and their introduction into the production; reduction of irrational budget costs and minimization of corruption schemes to steal budget (Skrypnychenko et al., 2012). Average growth of GDP in Ukraine during 2000-2015 at the level 4.03\% can signal about appearance of economy's recession prerequisites in the perspective period. The increasing tendency in the absolute terms of the country's GDP volume contradicts the unemployment rate increase during the last three years of the investigated period to $9.3 \%$ that keeping the proper tendency may have a negative impact on social and economic indices of people lives. It should be noticed that the consumer price index was greatly reduced in 2016 in comparison with previous year $(43.3 \%$ in 2015 , $13.9 \%$ in 2016). It can be explained with moderate fiscal and monetary policy of the country, with reduction of military conflict intensity in the east. 


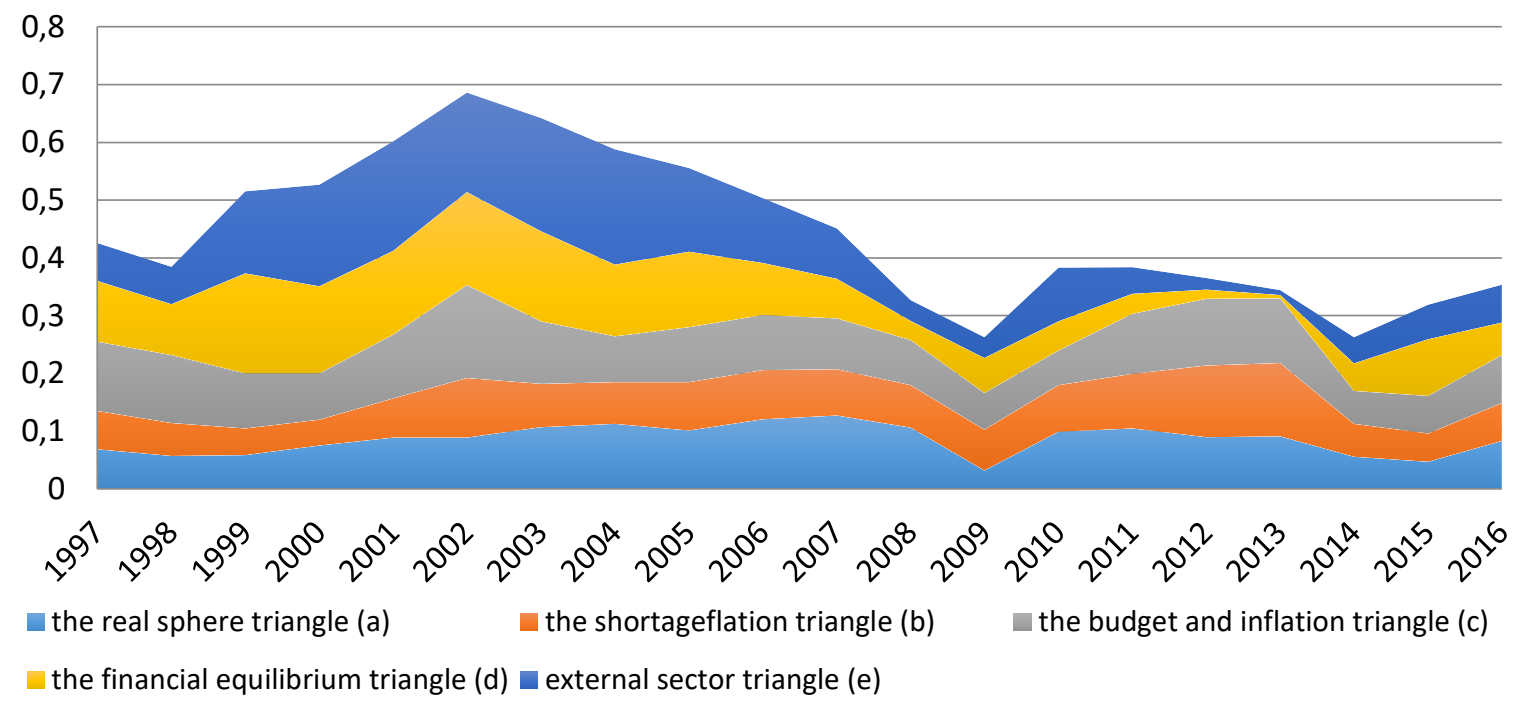

Figure 4. Distribution of MSP for Ukraine in 1997-2016

The analysis of the macroeconomic stability in Ukraine during 1997-2016 considering structure of internal (sum of surfaces of triangles $a, b$ and $c$ ) and external factors' (sum of surfaces of triangles $d$ and $e$ ) impact at different stages of the economic cycle: establishment of the post-Soviet economic system (1991-1998), pre-crisis period (1999-2007), crisis period (2008-2013) and post-crisis period (2014-2016) demonstrates chaotic process of economy stabilization and different orientation of the country's macroeconomic proportion (Figure 3 ).

Maximum value of MSP (0.69) was achieved by Ukraine in 2002 when there was a relative balance between MSP1 (0.35) and MSP2 (0.33). Since 1997 till 2003 triangles of financial balance and external sector were constantly growing (Figure 4) and in 2003 index MSP2 was the highest among all analyzed years (level of subindex MSP2 grew from 0.17 in 1997 to 0.35 in 2003 or by $105 \%)$. It should be noticed that during the whole time from 1997 till 2016 sufficient rate of the macroeconomic stability, higher than 0.5 , was demonstrated by the country only in the pre-crisis period from 1999 till 2007. During the mentioned period, except 1999 and 2000, internal factors (fields of triangle $a, b$ and $c$ ), had large specific weight in the MSP structure during the analyzed period and were within the range of 38\% (1999) and 65\% (2007).
In 2008 the situation worsened mainly due to external factors (MSP2 level was 0.07), and, first of all, it was a consequence of the global financial and economic crisis impact. During the whole crisis period in 2008-2013 subindex MSP2 was decreased and had minimum value in 2013 ( 0.02 or $5 \%$ of MSP). A large specific weight of the subindex MSP1 in 2008-2013 proves that macroeconomic situation in the country depends firstly on the native production.

During the stabilization process after post-crisis period both external and internal factors assisted the increasing of the macroeconomic stability level. Four of five triangles $(a, b$ and $d, e$ ) described positive dynamics; however large specific weight of internal factors (in 2016 about $66 \%)$ shows the gradual policy of the markets openness and GDP growth increase. In 2016 MSP rate (0.353) was 0.027 points higher in comparison with $2008(0.326)$ and 0.09 points higher than in 2009. Whereas fields of economy real field, stagflation, budget and inflation triangle in comparison with 2013 were decreased by $0.008,0.061$ and 0.029 points respectively. It should be pointed out that MSP rate in 20142016 did not reach minimum value during precrisis period since 1999 to 2007 (0.451 in 2007).

Average value of triangles squares of the synthetic index MSP during the whole analyzed period 


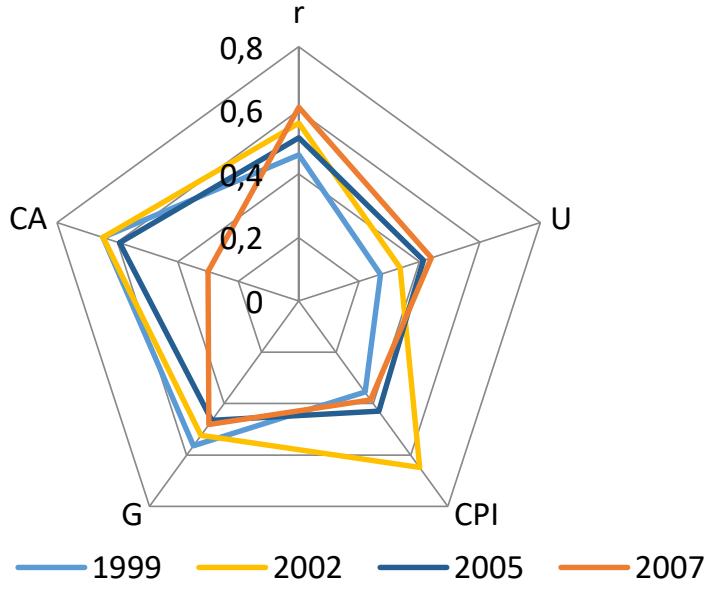

Pre-crisis period (1999-2007)

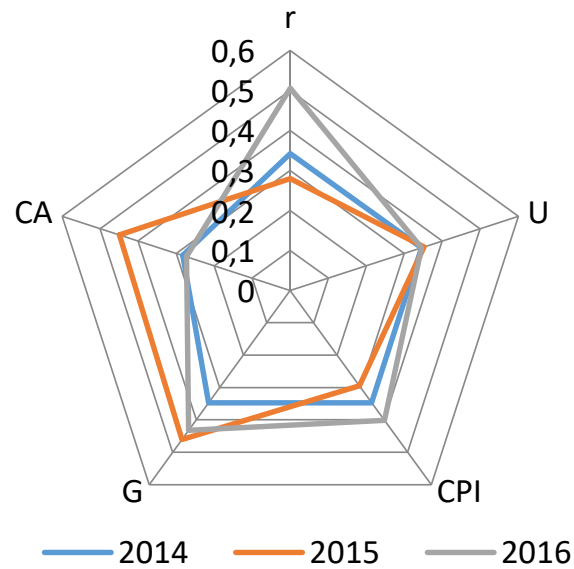

Post-crisis period (2014-2016)
Source: Formed on the basis of authors calculations.

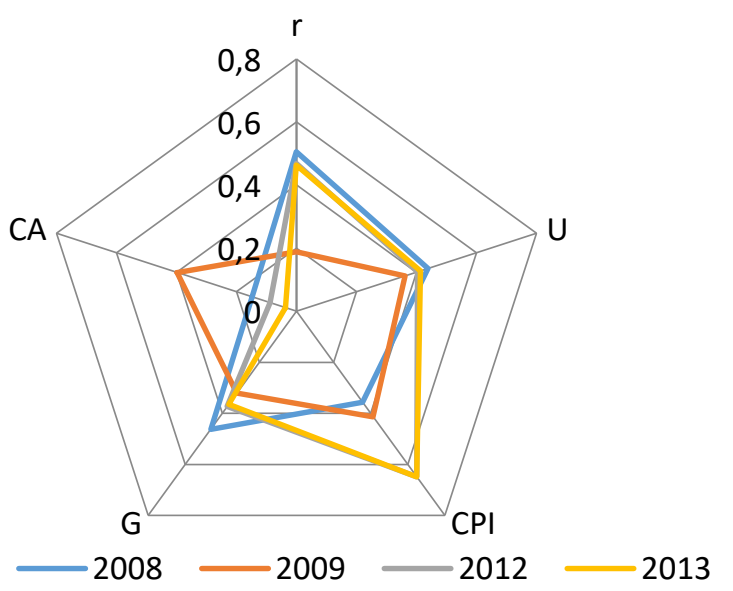

Crisis period (2008-2013)

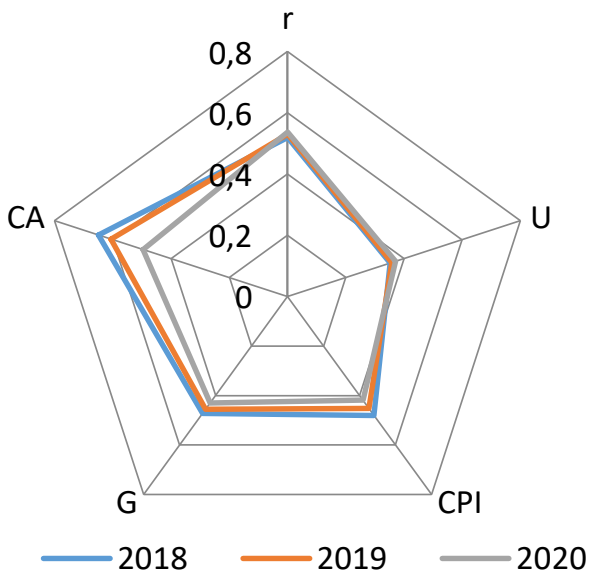

Predicted values (2018-2020)

Figure 5. Comparison of MSP profiles in Ukraine at different stages of the economic cycle

did not exceed an optimal value $0.1(a-0.086, b-$ $0.076, c-0.094, d-0.089$ and $e-0.098)$.

Given the macroeconomic predictions for Ukraine of GDP rate growth, unemployment rate approved on May, 31 at the meeting of Cabinet of Ministers of
Ukraine and based on data extrapolation concerning consumer price index, state budget balance, current account balance, one may state (Figure 5) that gradual improvement of the macroeconomic stability in 2018-2020 will be mainly by means of external and internal factors balance increase.

\section{CONCLUSION}

The macroeconomic stability pentagon conception, based on five basic macroeconomic indices: GDP growth rate, unemployment rate, inflation rate, balance of state budget to GDP, balance of current turnovers to GDP, was used during the investigation of the macroeconomic stability.

The MES pentagons empiric analysis results for Ukraine at different stages of the economic cycle establishment of post-Soviet economic system (1991-1998), pre-crisis period (1999-2007), crisis period (2008-2013) and post-crisis period (2014-2016) demonstrates chaotic process of the economy stabiliza- 
tion and different orientation of the country's macroeconomic proportion. Statistic indicator of MSP is calculated, maximum value of which was reached in 2002, when there was a relative balance between internal factors MSP1 and external factors MSP2. During the whole time since 1997 to 2016 the macroeconomic stability sufficient level, higher than 0.5 , was demonstrated by the country only in the precrisis period 1999-2007.

Ukraine's MSP profile for the period 2018-2020 was constructed, based on the macroeconomic predictions for Ukraine concerning GDP rate growth, unemployment rate, approved by the Cabinet of Ministers of Ukraine, and based on data extrapolation concerning consumer price index, state budget balance, and current account balance. It proves that macroeconomic stability is gradually improved by means of external and internal factors balance increase.

\section{REFERENCES}

1. Calin, A. L. (2013). Analysis of Romanian Economic Stability In Terms of Evolution of the Budgetary Deficit and Other Macroeconomic Indicators, In the Period 2005-2012. Annals of Faculty of Economics, 1(2), 287-295.

2. Hurduzeu, G., \& Lazar, M. I. (2015). An Assessment of Economic Stability under the New European Economic Governance. Management Dynamics in the Knowledge Economy, 3(2), 301-315. Retrieved from https:// www.ceeol.com/search/articledetail?id=596271

3. Ionita, R. O. (2015). The Evolution of the Macroeconomic Stabilization Pentagon in Romania, Czech Republic and Hungary. The Annals of the University of Oradea, 24(1), 733-741.

4. Kolodko, G. W. (1993). Stabilization, recession and growth in a post-socialist economy. Economic Journal on Eastern Europe and the Soviet Union, 3(1), 3-38.

5. Lyulyov, O., \& Shvindina, H. (2017). Stabilization pentagon model: application in the management at macro- and micro- levels. Problems and Perspectives in Management, 15(3), 42-52.

6. Malina, A., \& Mierzwa, D. (2014). The Impact of the Global Crisis on the Macroeconomic Stability of the Countries of Central and Eastern Europe and Germany. Knowledge Economy Society. Contemporary organizations in the process of institutional transformations. Foundation of the Cracow University of Economics, Cracow, 13-24.

7. MIP (2017). Macroeconomic Imbalance Procedure Scoreboard. European Commission. Retrieved from https://ec.europa.eu/info/ business-economy-euro/economic-and-fiscal-policy-coordination/ eu-economic-governance-monitoring-prevention-correction/ macroeconomic-imbalance-procedure/scoreboard_en

8. Regulation (2011a). Regulation (EU) No. 1174/2011 of the European Parliament and of the Council of 16 November 2011: On enforcement measures to correct excessive macroeconomic imbalances in the euro area. Official Journal of the European Union, $L$ 306, 8-11. Retrieved from http:// eur-lex.europa.eu/legal-content/ EN/ALL/?uri=celex:32011R1174

9. Regulation (2011b). Regulation (EU) No. 1176/2011 of the European Parliament and of the Council of 16 November 2011: On the prevention and correction of macroeconomic imbalances. Official Journal of the European Union, L 306, 25-32. Retrieved from http://eur-lex. europa.eu/legal-content/en/ TXT/?uri=celex\%3A32011R1176

10. Skrypnychenko, M. I. (Eds.) (2012). Фактори макроекономічної нестабільності в системі моделей економічного розвитку [Faktory makroekonomichnoi nestabilnosti $v$ systemi modelei ekonomichnoho rozvytku] (720 p.). The National Academy of Sciences of Ukraine, Institute for Economics and Forecasting, Kyiv.

11. WEF (2017). The Global Competitiveness Report 2017-2018, 2009-2010, 2008-2007, 2004-2005. World Economic Forum, Geneva. Retrieved from http//www.weforum.org

12. World Bank (2017). World Development Indicators 2017. Washington, DC: World Bank. Retrieved from http://hdl.handle. net/10986/26447

13. Żuchowska, D. (2013). Assessment of the Central and Eastern Europe Economies in the Years 2007-2010 Based on the Model of the Macroeconomic Stabilization Pentagon. Equilibrium. Quarterly Journal of Economics and Economic Policy, 8(4), 49-64. 